\title{
LINGUODIDACTICA XX
}

DOI: 10.15290/lingdid.2016.20.19

\author{
dr hab. Krzysztof Polok \\ Akademia Techniczno-Humanistyczna w Bielsku-Białej \\ Katedra Anglistyki \\ tel. 602574561 \\ e-mail: swortran@interia.pl
}

\section{INSTRUMENTY PRACY W GLOTTODYDAKTYCE}

\section{STRESZCZENIE}

Artykuł odnosi się do szeregu kwestii dotyczących sposobów przekazu wiadomości językowych w zakresie języka obcego przy wykorzystaniu szeregu instrumentów, które oferuje nauczycielowi języka glottodydaktyka. Artykuł wskazuje bardziej szczegółowo na dwa główne instrumenty glottodydaktyczne, jakimi są psycholingwistyka i dydaktyka, ale w oddali widać wyraźnie szereg instrumentów pozostałych, takich jak glottofilozofia, kultura języka czy semantyka.

Słowa kluczowe: glottodydaktyka, system nauczyciel-uczeń, języki obce

\section{SUMMARY}

\section{On the Instruments of Work of a FL Teacher}

The paper discusses a number of issues relating to the transference of language-orientated L2 issues with the help of a number of instruments that are offered by glotto-didactics to any L2 teacher. More importantly, the paper looks at the two glotto-didactic instruments, i.e. psycholinguistics and didactics, not forgetting about such instruments - appearing in distanced twilight - as glotto-philosophy, language culture, or semantics, that are also being mentioned in the paper.

Key words: glotto-didactics, T-L syndrome, foreign languages 


\section{Skrótowy przegląd elementów składowych glottodydaktyki}

Wszelkie instrumenty podstawowe, jak również różne rodzaje instrumentów pomocniczych wspomagających istotnie działanie instrumentów głównych, stanowią razem dosyć skomplikowaną orkiestrę, która - po to, aby wydać czyste i niezafałszowane dźwięki - musi mieć na tyle kompetentnego dyrygenta, który będzie wiedział, jak tę całą napierającą ze wszystkich stron siłę ujarzmić i poprowadzić ku harmonijnej współpracy oraz działalności mającej na celu uzyskanie pragmatycznych korzyści przez wszystkie osoby biorące udział w jej funkcjonowaniu. Z jednej strony istnieje więc glottodydaktyka - nauka o zasadach, formach, technikach i sposobach nauczania języków obcych, z drugiej zaś - szereg osób pragnących zobaczyć i przekonać się na własnej skórze, na ile istniejące i możliwe do zastosowania techniki i zasady nauczania/uczenia się języka obcego mogą sprawdzić się w każdym indywidualnym przypadku. Pozycja dyrygenta bądź też, jak kto woli, zdolnego mechanika, widzącego w jaki sposób przykręcić, dokręcić i wyregulować wszystkie śrubki znajdujące się wewnątrz mechanizmu zwanego procesem przyswajania języka, wydaje się w tym momencie na tyle istotna, że nie można się bez niej obejść.

Jednym $\mathrm{z}$ istotnych filarów glottodydaktyki jest psycholingwistyka. Jest to nauka, która - jak stwierdzili w swojej książce J. Berko Gleason i N. Bernstein Ratner $^{1}$ - opisuje procesy psychiczne pomagające ludziom zarówno na opanowanie, jak i na posługiwanie się językiem. Zainteresowania psycholingwistyki skupiają się głównie na fenomenie przyswajania języka przez ludzi. W tej materii psycholingwistyka formułuje wiele teorii, przedstawia szereg modeli, określa możliwe sposoby działania (i dziania się) stworzonych wcześniej koncepcji. Fenomen przyswajania oraz - w późniejszym okresie - wykorzystania języka przez człowieka, magazynowania szeregu informacji językowych w umyśle ludzkim, a następnie ich przetwarzania w konkretnych, aktualnie istotnych celach przez człowieka jest zjawiskiem na tyle ciekawym i na tyle niezrozumianym, że psycholingwistyka znajduje tutaj ogromne pole do działania. Współdziałanie cech wewnętrznych (np. woli człowieka) oraz cech zewnętrznych (np. środowiska) w procesie przyswajania sobie szeregu wiadomości o charakterze językowym, wskazuje na dosyć ścisły związek psycholingwistyki i nauk pokrewnych, takich jak psychologia, neurolingwistyka, socjolingwistyka, czy nawet kontakty z pewnymi obszarami medycyny. Oprócz tego psycholingwistyka szeroko sięga po wiele wiadomości związanych

$1 \quad$ N. Ratner, J. Gleason, Psycholinguistics, Harcourt 2005. 
z semiotyką, semantyką oraz kulturą języka, głównie po to, aby lepiej zrozumieć szereg zjawisk związanych $\mathrm{z}$ istotą języka oraz wpływem jego poszczególnych jednostek na sam proces poznawczy.

$\mathrm{Z}$ jednej strony jest więc psycholingwistyka instrumentem łączącym kwestie zdecydowanie psychologiczne z kwestiami językowymi różnego formatu, z drugiej zaś zahacza o zagadnienia natury kulturowej, socjologicznej, a nawet medycznej ${ }^{2}$. W ten sposób zagadnienia np. motywacji, zawsze oparte na świadomym dążeniu do intensyfikacji poznania, łączą się z szeregiem kwestii językowych, opartych o chęci lepszego zrozumienia doświadczanej rzeczywistości, pełniejszego jej poznania, oraz możliwości jej opowiedzenia. Nauka reakcji na różnego rodzaju bodźce zewnętrzne, odpowiedniej ochrony, tak psychicznej, jak i fizycznej, zawsze była jednym z podstawowych elementów bytu; człowiek niepotrafiący zareagować w odpowiednio skuteczny sposób na dochodzące z zewnątrz, spoza sfery kognicji, różnego rodzaju sygnały, staje się jednostką bezbronną, bezradną wobec napotykanych wyzwań. Jedynym sposobem obrony przed tego rodzaju sytuacją jest umiejętność jej właściwej oceny oraz - następnie - wykorzystanie w charakterze skutecznej tarczy, logicznie wynikających z tego szacunku środków zaradczych. Rezerwuar takich środków przechowywany jest w ludzkiej pamięci, a sposoby przekonania się o ich skuteczności są, w gruncie rzeczy, dwa: albo przy pomocy empirycznego doświadczenia, opartego o wcześniejszą analizę zaistniałej sytuacji (o czym skutecznie przekonywał już J. Dewey), albo też dzięki skorzystaniu z informacji uzyskanych - przy pomocy języka właśnie - od innych osób (informacji w wielu przypadkach również opartych na empirii). Po to jednak, aby człowiek był w stanie z tej drugiej możliwości skorzystać, powinien poznać stworzony przez kulturę danego języka system pozwalający na skuteczne przyswojenie sobie konkretnych informacji. To właśnie owe wewnętrzne, istniejące w człowieku, możliwości opanowania takiego systemu, a następnie w miarę bezkolizyjnego jego wykorzystywania, są głównym i zasadniczym polem działania istotnego instrumentu glottodydaktycznego zwanego psycholingwistyką.

Historia rozwoju psycholingwistyki zaznaczona jest wieloma ważnymi zwrotami, poczynając od tych najbardziej zewnętrznych (np. osiągnięcia behawioryzmu), do tych wchodzących coraz szerzej i coraz głębiej w wewnętrzną naturę człowieka (np. nowe modele konstrukcji myśli, innatyzmu, bądź NLP). Wykazanie, że nacisk na tworzenie zjawiska nawyku podczas procesu zdobywania informacji natury językowej współgra, w pewnym sensie, z wewnętrznym zjawiskiem woli (co, z kolei, łączy się z szerokim zagadnieniem manipulowania warstwami motywacyjnymi) dało impuls do rozwoju psychologicznej warstwy w psycholingwistyce, czego wyrazem było chociażby tak silne podkreślenie funkcji

2 Zob. G. Yule, The Study of Language, Cambridge 1998. 
rozumu (oraz filozoficzne uzasadnienie jej roli podczas procesu nauki mówienia). Wskazanie, z kolei, na istotność myśli (oraz jej zdefiniowanie) przyczyniło się do bardziej szczegółowego zwrócenia uwagi na funkcje, jakie myśl ludzka odgrywa w tworzeniu się kognitywnej siatki pojęć w umyśle człowieka, oraz sukcesywne wypełnianie jej językowo istotnymi wiadomościami. Równocześnie jednak obie kwestie zwróciły uwagę naukowców na społeczne funkcje pełnione przez język oraz jego rolę nie tylko w całościowym procesie dostosowywania się człowieka do otaczającej go rzeczywistości, ale również w nieustannych próbach odszyfrowania i skutecznego porządkowania sygnałów dochodzących z zewnątrz. W ten sposób przyczynia się psycholingwistyka do wytworzenia się szeregu propozycji zrozumienia przez człowieka samego fenomenu poznania zjawiska funkcjonowania języka oraz - w miarę skutecznego - opisu postępowania podczas przyswajania, przetwarzania oraz wykorzystywania przez człowieka danego systemu opisu rzeczywistości do konkretnych, aktualnie istotnych, celów.

W tym miejscu należy bardzo wyraźnie podkreślić istotność zjawiska motywacji podczas procesu przyswajania języka ${ }^{3}$. Właściwe proporcje woli i chęci w samym procesie świadomego przyswajania i poznawania norm operacjonalizacyjnych systemu (głównie) drugiego języka odgrywają rolę niebagatelną i są nie do przecenienia. Zakładając dużą rolę wpływu motywacji na sam proces nauki języka, podkreślić trzeba funkcje, które motywacja do nauk języka odgrywa podczas tworzenia się całościowego obrazu złożoności tego zjawiska w kognicji ludzkiej. Kształtujące się w różny sposób zmienne chęci, zainteresowania, głodu wiedzy, nasycenia informacjami różnego typu, różnych bodźców psychicznych (takich jak np. ocena zewnętrzna i jej kompatybilność $z$ indywidualną oceną wewnętrzną) oraz szereg różnych niewymienionych tutaj zjawisk ogólnie wypełniają całościowy obraz zwany świadomym poznawaniem języka. Opisywanie drogi, którą przejść musi każdy uczeń uczestniczący w świadomym procesie nauki języka, jego psychologicznie wytłumaczalnych wahnięć nacechowanych - w mniejszym lub też większym stopniu - pozytywnie bądź negatywnie jest instrumentem naukowo istotnym (a także pragmatycznie nie do przecenienia), ponieważ stanowi ważną wskazówkę dla każdej osoby, która także ma zamiar rozpoznać się w sposobach opisu rzeczywistości zawartych w innych od rodzimego systemach językowego opisu. Jest to instrument o tyle istotny, że jego działanie oraz jego skuteczność uzależnione są nie tylko od atmosfery wewnętrznej, ilustrującej aktualny stan umysłu i duszy człowieka, lecz także od okoliczności zewnętrznych, od których w dużym stopniu zależy sposób podejmowania każdego kolejnego działania mającego pomóc człowiekowi w wypełnieniu konkretnych założeń. Przedstawione

3 Zob. S. Andrews, Teacher language awareness, Cambridge 2007, s. 89-90. 
w tekście zagadnienia motywacyjne, demotywacyjne oraz amotywacyjne, a także wiele innych, mających z nimi bardziej lub mniej ścisły związek (takich jak sylwetka i kształtowanie się pojęcia ucznia leniwego lub też cały szereg kwestii związanych z teorią inteligencji wielorakich) z pewnością nie wyczerpują całości zagadnienia, są jednak - jak można sądzić - sygnałem wysłanym osobom wczytującym się w przedstawioną problematykę, iż warto czasem skupić się nad tym instrumentem wspomagającym naukę zwaną glottodydaktyką.

Drugim z podstawowych instrumentów jest dydaktyka. Zasadniczym polem działania dydaktyki jest - co pośrednio wynika z samej nazwy - opis świadomych form postępowania mających na celu pełniejsze i bardziej efektywne nauczanie (oraz uczenie się) konkretnych dziedzin wiedzy przez człowieka ${ }^{4}$. Wychodząc z założenia, iż świadome poznanie oparte jest z jednej strony na instrukcji, z drugiej zaś na konkretnym zastosowaniu praktycznym przekazanej właśnie instrukcji, dydaktyka zajmuje się zarówno tworzeniem hipotez związanym właśnie z owym procesem nauczania/uczenia się, jak i ich sukcesywnym sprawdzaniem oraz - następnie - wprowadzaniem w życie w wypadku logicznie pozytywnej oceny konkretnych efektów takiego procesu. W tym konkretnie wypadku, ponieważ proces ten odnosi się do świadomych działań ludzkich, dydaktyka jest instrumentem współgrającym ściśle z innymi dziedzinami wiedzy, takimi jak psychologia, pedagogika, socjologia bądź neurologia, po to, aby wiele informacji z danych dziedzin wykorzystać, przetworzyć oraz wdrożyć do własnych celów. Jest więc dydaktyka nauką w pełni eklektyczną, mającą na celu wykorzystanie wszelkich środków, mogących odegrać niebagatelną rolę w procesie systematycznego objaśniania rzeczywistości oraz jej umiejętnego systematyzowania. Stworzone zostały konkretne reguły dydaktyczne służące człowiekowi do pomocy w świadomym postępowaniu związanym z rozpoznawaniem oraz zapamiętywaniem konkretnych sygnałów semiotyczno-semantycznych, składających się na dany system językowy. Głównym przesłaniem dydaktyki, także i w tym wypadku, jest więc stworzenie propozycji działań na tyle skutecznych i logicznie spójnych, by w efekcie stwarzały one efektywnie i pragmatycznie spinający się system świadomego objęcia przez człowieka całej sekwencji różnych form oznaczeń dowolnego typu składających się na skuteczny opis otaczającej człowieka rzeczywistości z jednej strony, oraz rodzących się subiektywnych odczuć i interpretacji owej rzeczywistości - z drugiej. Jest to więc instrument w miarę spójny, w miarę szczegółowy oraz w miarę skuteczny, pozwalający na jego zastosowanie w konkretnych sytuacjach, w celu uzyskania możliwych efektów pedagogicznych, które będzie można dostrzec podczas późniejszego użycia języka przez uczniów podczas proponowanych przez nich wersji

4 F. Bereźnicki, Podstawy dydaktyki, Kraków 2011, s. 13-17. 
(zewnętrznego oraz wewnętrznego) opisu odbieranej rzeczywistości. To właśnie w tej sytuacji wyraźnie będzie można zauważyć związek dydaktyki z innymi dziedzinami wiedzy (np. socjologią bądź nawet filozofią) oraz wykorzystania szeregu znajdujących się tam informacji do własnych celów ${ }^{5}$.

Usystematyzowanie działań dydaktycznych wymagać będzie od nauczycieli oraz uczniów zastosowania nie tylko konkretnych metod, technik bądź procedur, lecz również własnego poglądu na to, czym konkretnie jest dana dziedzina wiedzy, a także po co związane z nią wiadomości potrzebne są uczniom. Jeśli bowiem nauka ma być efektywna, skuteczna oraz pragmatycznie logiczna, musi ona ułatwiać człowiekowi jego działania związane z całościowym oglądem rzeczywistości, w której tkwi. Należy więc poszukać, a następnie rozważyć istotność zastosowania takich form przekazu systematyzowania informacji konkretnego typu, aby zostały one uznane przez człowieka za ważne, pomocne oraz względnie nieskomplikowane, aby można je było zastosować w celu zoptymalizowania ilości informacji. Każda lekcja szkolna oparta więc będzie nie tylko o elementy wewnętrzne (np. chęć poznania i przyswojenia sobie informacji danego typu), lecz także o szereg elementów zewnętrznych, zahaczających o struktury i formy procesu uczenia (się) wypracowane przez wielu animatorów procesu kształcenia i - co istotne - przez nich rekomendowane.

Nie oznacza to jednak, że dydaktyka jest instrumentem skostniałym, w którym dużą (o ile nie decydującą) rolę odgrywa wypracowana wiele lat wcześniej strategia przekazu wiedzy. Już w 1943 r. B.F. Skinner stwierdził, iż pomiędzy uczeniem się i nauczaniem zachodzi podobna relacja, jak pomiędzy nauką i sztuką ${ }^{6}$. O ile bowiem uczenie się oparte jest w wielu sytuacjach na poznaniu wewnętrznych możliwości ucznia, oraz - następnie - wykorzystaniu owych możliwości do w miarę skutecznego kontaktu ucznia z wiedzą, o tyle działalność nauczyciela ma w sobie wiele wspólnego ze sztuką, ponieważ zasadza się na kreatywnym tworzeniu. W tym kontekście właśnie dydaktyka jest dziedziną tętniącą życiem, instrumentem, który potrafi zmienić swoją barwę formą postępowania zakładającą od samego początku kontakt $\mathrm{z}$ myśleniem dywergencyjnym. W oparciu o indywidualne przekonania nauczyciela, związane silnie $\mathrm{z}$ ukształtowanym w jego umyśle oglądem głównych cech nauczanego przedmiotu, należy stworzyć obraz lekcji, który w pełni odpowiadać będzie konkretnemu, zależnemu od wielu warunków wewnętrznych i zewnętrznych zapotrzebowaniu na wiedzę, obraz, który nigdy nie może być obrazem statycznym, lecz który musi podlegać ciągłej projekcji, analizie i dostosowaniu go do dynamicznie zmieniającej się sytuacji. W tym kontekście

\footnotetext{
Ibidem, s. 68-69.

6 B.F. Skinner, The Science of Learning and the Art of Teaching, „Harvard Educational Review” 1954, 24, s. 86-97; przedruk: Readings for reflective teaching, A. Pollard (red.), Amsterdam 2002, s. 106-109.
} 
każdy nauczyciel jest twórcą, artystą przekuwającym swoje odczucia i przekonania w całościowy obraz lekcji, mającej przecież dostarczyć uczniom doświadczeń zarówno intelektualnych, jak i emocjonalnych.

Nauka języka nie może więc być jedynie formą fizycznej obecności nauczyciela w klasie, w trakcie której pełnić on będzie głównie funkcje nadzorcze i oceniające. Nauka języka, podobnie jak - w pewnym sensie - nauka innych przedmiotów - stanowić powinna proces ciągły, kreatywny, zadowalający uczniowskie oczekiwania, oraz - co równie istotne - skuteczny. Nauczyciel powinien być w stanie zaplanować taki system działań lekcyjnych, aby uczniowie dostrzegli w nim zarówno pragmatycznie określone cele długoterminowe, jak i spełniające ich wymogi i oczekiwania cele estetyczne. Będąc biegłym (w miarę) użytkownikiem języka, którego uczy, powinien nauczyciel wiedzieć, w jaki sposób dawkować różne, znane mu formy i techniki nauki języka, aby ów proces kontaktów językowych nie był procesem nużącym, skupiającym uwagę uczniów na różnego typu samoistnie pojawiających się trudnościach związanych z opanowaniem konkretnych informacji językowych, lecz aby w wielu formach dydaktycznych promujących dynamizm, które nauczyciel zdecydował się zastosować podczas lekcji językowej, uczniowie mogli osiągnąć skuteczny i efektywny wzrost biegłości językowej.

Dla osób z zewnątrz, niezbyt uważnie rozpoznających specyfikę działalności nauczycielskiej, działalność polegająca na nauczaniu nie wydaje się czynnością zbyt skomplikowaną. Nauczyciel jest tutaj definiowany jako osoba posiadająca wiedzę, a także umiejętności skutecznego przekazywania jej uczniom. Jest to więc definicja oparta na klasycznej „oglądowej” działalności edukacyjnej i nie różni się bardzo od tego opisu sylwetki nauczyciela, którą wiele lat temu proponował Platon ${ }^{7}$. Główną, aczkolwiek zasadniczą różnicą jest tutaj fakt, że zgodnie z zamysłem Platona, głównym celem działalności edukacyjnej nauczyciela było odtwarzanie stałej i niepodzielnej, a więc także nieposzerzającej się wiedzy, obecnie zaś dopuszcza się, zgodnie z przedstawioną powyżej definicją, zarówno możliwość dodawania nowych informacji, jak i ulepszanie sposobów przekazywanej wiedzy w oparciu o wciąż pojawiające się różnego rodzaju nowinki techniczno-edukacyjne. W dalszym ciągu jednak niezbyt często zauważany zostaje fakt, że praca nauczyciela oznacza faktycznie cały szereg niezwykle precyzyjnych operacji, podczas których podmiotem i polem działania pozostaje umysł ucznia. Z tego powodu, w wielu wypadkach, każde tego typu działanie edukacyjne może zostać porównane (z niewielkim jedynie ładunkiem metaforyki) do pracy kardiologa, lub - jeszcze lepiej - neurochirurga; w obu sytuacjach, jeden niezbyt przemyślany (nieprecyzyjny) uczynek może skutkować niemożliwymi do przewidzenia rezultatami.

7 D.H. Phillips, J.F. Soltis, Perspectives on learning, London 2004, s. 21-24. 


\section{2. „Uczenie się jest dziedziną wiedzy, nauczanie zaś - sztuką”}

Jakkolwiek w opisanym powyżej systemie zamkniętym U - N, to uczeń jest elementem poszukującym wiedzy oraz - następnie - w odpowiedni sposób ją asymilującym, zadanie elementu bezpośrednio z nim sprzężonego, czyli nauczyciela, jest nie tylko równie odpowiedzialne, lecz także stymulujące. Z jednej strony powinien nauczyciel umieć dopasować przekazywane informacje do pojemności aparatu informacyjnego ucznia w ten sposób, aby zostały one przez niego kognitywnie zauważone, $\mathrm{z}$ drugiej zaś dostarczyć mu tej całej gamy odczuć i zachęt, przy pomocy których będzie uczniowi łatwiej przebrnąć przez cały proces uzyskiwania obrazu efektywnie poszerzającego zakres jego wiedzy. Powyższe zadanie w dosyć ścisły sposób opisywane jest przez zacytowaną powyżej w podtytule lapidarną opinię, która została wypowiedziana około pięćdziesiąt lat temu przez jednego z czołowych twórców teorii behawioralnej, B.F. Skinnera ${ }^{8}$. Mimo upływu czasu ani trochę nie straciła ona na ostrości. Jeśli bowiem przyjmie się założenie, iż proces uczenia się oparty jest na serii działań psychologiczno-kognitywnych (w szerokim znaczeniu tego określenia), to cały proces nauczania określony zostać powinien jako sztuka chociażby z tego powodu, że oznacza on wczuwanie się w możliwości percepcyjne uczniów oraz stosowanie takich form przekazu informacji, aby stały się one w miarę skutecznym transporterem treści wiedzy. Pojawia się więc tutaj pojęcie interakcji ${ }^{9}$, a cały proces nauczania stający się specyficznie rozumianym procesem komunikowania się, stanowi dosyć wyraźnie sprecyzowany element gry aktorskiej ${ }^{10}$. Jeśli bowiem przekaz informacji (w dowolnej formie) uznany być może za sposób komunikowania się przebiegający w zgodzie z ogólnie przyjętymi kryteriami komunikowania się, nauczanie takie w pełni kryteria te wypełnia ${ }^{12}$. W oparciu zaś o teorię interakcjonizmu stworzoną przez E. Goffmanna, proces nauczania oznacza konieczność wczucia się w rolę określoną kulturowo jako 'nauczyciel' oraz, później, postępowania w zgodzie z brzegowo określonymi kryteriami (tj. formami społecznej akceptacji). Nauczyciel uczestniczy tutaj w „przedstawieniu dramaturgicznym", w którym zarówno on, jak i uczniowie odgrywają role

8 Ibidem.

9 E. Goffmann, Człowiek w teatrze życia codziennego, Warszawa 1974 [1981], s. 14.

10 Można wręcz zauważyć, że komunikowanie się w dużym stopniu determinuje istnienie społeczeństw, a niektórzy z badaczy twierdzą nawet, że procesy komunikacyjne stanowią „fundament społeczeństwa, bez których nie mogłoby ono funkcjonować, trwać i dokonywać transmisji dziedzictwa kulturowego z pokolenie na pokolenie" (zob. B. Dobek-Ostrowska, Podstawy komunikowania społecznego, Wrocław 1999, s. 7).

11 Ibidem, s. 14-15.

12 Zob. np. J. Fiske, Introduction to Communication Studies, 2000, s. 2 i nast. 
aktorów $^{13}$. Rola reżysera przedstawienia tego typu, którym także jest nauczyciel ${ }^{14}$, niemniej istotna $\mathrm{z}$ dydaktycznego punktu widzenia, stanowi tutaj o jakości talentu nauczyciela oraz o jakości uzyskanych przez niego wyników dydaktycznych.

W tym kontekście omówić należy rolę nauczyciela języków obcych i to zarówno z punktu widzenia ucznia (a także jego rodziców), jak i samego nauczyciela. Jak sądzimy, opis ów rozpocząć można od w miarę dokładnego sprecyzowania działalności szkolno-edukacyjnej. Ponieważ jest to, zasadniczo, działalność oparta na przekazywaniu wiedzy, zarówno uczniowie, jak i ich rodzice oczekują, że każda lekcja dostarczy jej uczestnikom tzw. 'twardej' wiedzy, zgodnej z podanym przez nauczyciela tematem oraz specyfiką przedmiotu. W ten sposób, każda lekcja geografii powinna dostarczyć uczniom konkretnej porcji świeżej wiedzy geograficznej, na lekcji historii uczniowie powinni zostać wzbogaceni kolejną porcją wiedzy historycznej, a na zajęciach z chemii poznać nowe tajniki wiedzy chemicznej. Postępując w ten sposób, uczniowie zgromadzeni na zajęciach języka obcego oczekują, że uzyskają dostęp do szeregu informacji (bądź też - szerzej - wiedzy), pomocnych w opanowaniu danego języka. Uczestnicząc w tego typu zajęciach, w dużej ilości wypadków, uczniowie oczekują, że dostarczą im one wiedzy pozwalającej na to, aby byli w stanie przy wykorzystaniu zgromadzonej 'twardej' wiedzy językowej - w miarę swobodnie komunikować się w wybranym języku obcym $^{15}$. W rozumowaniu tym pojawia się jednak pewna, brzemienna w skutkach, niekonsekwencja (bądź też skrót myślowy). Żadna lekcja języka obcego (w rozumieniu lekcji języka obcego, nie zaś lekcji o języku obcym) nie jest w stanie dostarczyć uczniom tego typu 'twardej' wiedzy, którą otrzymują oni na lekcjach geografii, historii lub chemii. Zadaniem lekcji językowej nie jest bowiem - jak w wypadku wspomnianych wcześniej innych dziedzin wiedzy - nauka o języku, lecz nauka języka (czyli komunikowania się w języku poznawanym przez uczniów).

13 B. Dobek-Ostrowska, op. cit., s. 60.

14 T. Rogers i J. Richards, proponując swoją koncepcję usystematyzowania pojęcia metody względem innych istotnych określeń działalności glottodydaktycznej, takich jak podejście (ang. approach) bądź też procedury (ang. procedure) wykorzystywane podczas procesu uczenia wprowadzają pośrednio związane z kwestią gry aktorskiej pojęcie projekcji (ang. design). Pojęcie to, odwołując się do koncepcji przestrzennej, ustawia zarówno nauczyciela, jak i ucznia w perspektywie scenariusza, umożliwiającego obu stronom odpowiednie „odegranie” kwestii przewidzianych przez reżysera lekcji (którym może być zarówno sam nauczyciel, jak i np. autor programu nauczania lub podręcznika, bądź też nawet nauczyciel i uczeń). Zob. J. Richards, T. Rogers, Approaches and Methods in Language Teaching, Cambridge 2001, s. 30-34.

15 Jest to więc podejście bardzo tradycyjne, akceptujące w całej rozciągłości szereg założeń metody podającej. Zob. H. Wichura, Metody kształcenia początkowego, [w:] Praca nauczyciela i ucznia w klasach 1-3, Warszawa 1990, s. 77-99, [online], http://www.edukator.org.pl/2005a/wspieranie/ wspieranie.html, [dostęp: 20.01.2016]. 
Specyfikacja ta oznacza, że pojawiająca się tutaj 'twarda' wiedza (np. informacje o postaciach systemu gramatycznego i/lub leksykalnego) stanowi zaledwie podstawę całej serii dalszych działań kształtujących ich kompetencję komunikacyjną; nie jest, jak widać, końcowym efektem działań edukacyjnych (tzn. opanowania konkretnych porcji wiedzy), a jedynie środkiem do celu.

Taka sytuacja stanowi dodatkową trudność w funkcjonowaniu zarówno nauczyciela, jak i ucznia. Z jednej strony uczeń musi zrozumieć, że specyfika lekcji językowej wymagać będzie od niego systematycznego zaangażowania się w praktyczne opanowanie (internalizację) poznawanych struktur leksykalnych i/lub syntaktycznych oraz, że będzie to - bardziej lub też mniej mozolne - wykonywanie całej serii zaproponowanych przez nauczyciela różnego rodzaju działań wprowadzająco-utrwalających konkretne kwestie językowe. Z drugiej zaś strony, prowadzący lekcję nauczyciel powinien umieć dostrzec, że wszelkiego typu formy oddziaływania na system kognitywny ucznia są zawsze relatywne i zależą od wielu czynników natury psychologicznej bądź społecznej. Uznawanie, przykładowo, że uczniom wystarczy jeden zaledwie sposób prezentacji materiału (co często - z pozytywnym skutkiem - ma miejsce na lekcjach geografii, historii lub chemii) prowadzi w efekcie do niepełnego opanowania konkretnej wiedzy językowej przez ucznia, co następnie skutkuje pojawianiem się różnego typu dziur informacyjnych. Nauczyciel nie może czuć się usatysfakcjonowany faktem, że podczas lekcji przedstawił uczniom strukturalne zasady działania (operacyjności) danego zjawiska językowego, po czym przedstawienie owo poparł (w oparciu o zasadę sprzężenia zwrotnego) zdawkowymi przykładami stanowiącymi treść znajdujących się w podręczniku ćwiczeń, ponieważ efekty takiego postępowania będą w zdecydowanej większości przypadków dalekie od oczekiwanych. Wiedza taka, jeśli nie zostanie dostatecznie ugruntowana, usystematyzowana oraz utrwalona podczas całej serii lekcji, następnie zaś na różne sposoby „przypominana” uczniom podczas cyklicznych lekcji powtórzeniowych, nigdy nie przeniknie w całości do warstwy internalizującej; zostanie uznana przez ucznia za wiedzę istotną do pracy nad najbliższym tekstem, później zaś ulegnie stopniowej deformacji i - w końcu - atrycji. Sytuacja taka może mieć miejsce, ponieważ nie każdy uczeń - z różnych powodów - rozumie sens pojęcia 'nauka języka' i w wielu przypadkach sprowadza je do kategorii rankingowych, w których oś rankingową stanowi opcja zero-jedynkowa typu 'znam - nie znam', multiplikowana następnie poprzez istniejący system ocen szkolnych. W szeregu wypadków uczeń uznaje, iż „zna” daną kwestię strukturalno-leksykalną, ponieważ był w stanie zrobić podczas zajęć lekcyjnych konkretne ćwiczenia książkowe (fakt ten stanowi dla niego pozytywną wersję sprzężenia zwrotnego), następnie zaś uzyskał, aprobującą jego działania, opinię nauczyciela. Jeśli jednak (co stanowić może swoisty rodzaj testu internalizacyjnego) uczeń samodzielnie za jakiś czas powróciłby do konkretnych ćwiczeń, 
które wcześniej sam umiał zrobić, w wielu wypadkach napotkać może na spore problemy $\mathrm{z}$ ich pozytywnym wypełnieniem. Potrzebna mu $\mathrm{w}$ tym wypadku wiedza formalna uległa już częściowej dylatacji bądź nawet całkowicie zanikła, uczeń zaś - w celu jej odtworzenia - zostanie zmuszony do ponownego przejrzenia określonej porcji materiału.

Sytuacji takich można jednak uniknąć, jeśli tylko proces pracy ucznia nad językiem zostanie odpowiednio zaprojektowany. Działania takie wymagać będą od nauczyciela skorzystania ze sporej dawki wiedzy ogólnopedagogicznej, która (po zmieszaniu jej z wiedzą językową dotyczącą specyfiki danego języka) powinna doprowadzić nauczyciela do stworzenia takiego projektu modelu lekcji językowej, który uwzględniałby w szerszym zakresie indywidualne potrzeby kognitywne każdego z uczniów. Ponieważ każdy uczeń stanowi odrębną jednostkę psychokognitywną, oznaczać to musi dla nauczyciela nie tylko konieczność poznania indywidualnych potrzeb każdego z nich, lecz również takie dostosowanie swoich działań edukacyjnych, aby w o wiele szerszym zakresie uwzględniały one indywidualne potrzeby uczniów. Tworzenie leksykonu mentalnego nowego poznawanego przez ucznia języka jest procesem żmudnym, niewdzięcznym, nietolerującym działań skróconych oraz długotrwałym. Działalność taka wymaga znacznego zaangażowania intelektualno-wiedzowego zarówno ze strony ucznia, jak i nauczyciela i nie można jej ograniczać do kilkunastu, często niezbyt fortunnie, dobranych ćwiczeń, które uczniowi udało się wykonać.

\section{Funkcjonowanie aparatu wiedzy z punktu widzenia nauczyciela języka}

Wiedza stanowi istotny element możliwości funkcjonowania człowieka. Zgodnie z ogólnie akceptowanymi założeniami wielu teoretyków nauki (np. Dewey’a, Feuersteina, Wygotskiego, Bandury, Piageta, oraz wielu innych ${ }^{16}$ ) człowiek nieposiadający wiedzy nie jest w stanie przeżyć we współczesnym (i nie tylko) świecie, ponieważ warunek sine qua non stanowi dla niego zdobyte i bez końca odtwarzane, funkcjonujące w jego pamięci długotrwałej doświadczenie. W ten sposób każda jednostka ludzka jest w stanie podejmować różnego rodzaju decyzje dotyczące swojego funkcjonowania, ponieważ umożliwia jej to, zamknięty w rezerwuarze pamięci, zasób doświadczeń. Jak wskazuje Dewey ${ }^{17}$, ilość doświadczeń zdobytych przez człowieka podczas jego kontaktów z otaczającą go rzeczywistością stanowi bezpośrednie przełożenie na jakość i sensowność podejmowanych

16 Zob. np. M. Williams, E. Burden, Psychology for Language Teachers, Cambridge 2007.

17 D.H. Phillips, J.F. Soltis, op. cit., s. 38. 
przez niego decyzji. Jeśli więc człowiek nie posiada pewnych porcji wiedzy, musi oprzeć swoje decyzje jedynie na tych wiadomościach, jakie rzeczywiście posiada, co w pewnych wypadkach okazać się może działaniem nie tylko niepełnym, lecz nawet - w pewnych okolicznościach - niebezpiecznym. Można stąd wyciągnąć wniosek, że zdobywanie wciąż nowych doświadczeń różnego rodzaju stanowić powinno oś życiową ludzkiej egzystencji, drastycznie warunkującą możliwości funkcjonowania człowieka w konkretnym środowisku.

W tym miejscu pojawia się gwałtownie potrzeba poszukania (i znalezienia) instrumentu, przy pomocy którego człowiek byłby w stanie w szybki i efektywny sposób zdobywać i przyswajać wszelkie nowe doświadczenia. Człowiek nie jest bowiem w stanie (czego oczekiwać się zdaje od niego Locke) samodzielnie zdobyć na tyle istotnej porcji doświadczeń, aby w miarę komfortowo (przy całej relatywności tego określenia) umieć funkcjonować w świecie, który codziennie oferuje mu ogromne ilości nowych wiadomości, z którymi powinien się zmierzyć, by - następnie - ocenić ich przydatność.

Kultura, w której człowiek funkcjonuje, instrument taki wymyśliła oraz odpowiednio przystosowała do stanu, w którym może być on wykorzystany do zbierania i oceny uzyskanych wiadomości. Instrumentem tym jest język, rozumiany jako endo-uniwersalny system znaków-kodów, pomagający użytkownikowi danej kultury w prawidłowym opisie lokalnej rzeczywistości ${ }^{18}$. Ów system znaków-kodów jest systemem oznaczonym i oznaczającym, co - z jednej strony - wskazuje, iż konkretne ustawienie znaków-kodów (foniczne i/lub graficzne) opisuje (tj. naznacza) dany jednostkowy desygnat rzeczywistości realnej, z drugiej zaś informuje, że każdy z istniejących w danym systemie kulturowym znaków-kodów może zostać wykorzystany do oznaczenia konkretnego kontekstowo umocowanego zjawiska kulturowo-realnego. System znaków-kodów kulturowo wykorzystywany do oznaczania małego kotka, może na przykład także znaleźć quasi-metaforyczne zastosowanie do oznaczania młodej, atrakcyjnej seksualnie, kobiety, przy czym pojawiające się tutaj różnego typu konotacje kulturowo-semantyczne oznaczają, w obu wypadkach, chęć zastosowania podobnej sekwencji sprawczej, czyli znajdowania przyjemności w przytulaniu i głaskaniu ustalonych kulturowo desygnatów. Jakkolwiek podany przykład służyć może także jako ilustracja dobrze umotywowanego seksizmu kulturowego, w miarę jasno obrazuje on dwojakość istniejącego kulturowego systemu znaków-kodów. W tym kontekście, oznaczenie to formalne przypisanie danego ciągu znaków-kodów do konkretnego zdarzenia (zdarzeń) kulturowego. Pozwala ono z kolei na zastosowanie przez użytkowników danego systemu kulturowego różnego rodzaju operacji metaforyczno-metonimicznych w celu opisu innego dowolnego segmentu tkanki kulturowej przy pomocy pewnego

18 Zob. C. Kramsch, Language and Culture, Oxford 1998. 
tradycyjnie wykorzystywanego do opisu innego zjawiska kulturowego ciągu znaków-kodów, o ile osoba proponująca zastosowanie takiej operacji wykaże istniejącą zgodę logiczną pomiędzy oboma zjawiskami kulturowymi. Przedstawione zjawisko stanowi inherentny element opisu językowego każdej kultury i prowadzi m.in. do pojawienia się kulturowo uwarunkowanych różnic semantyczno-językowych pomiędzy różnymi systemami kulturowymi (zob. słabsza wersja hipotezy Sapira i Whorfa $)^{19}$.

Nakreślony powyżej szkic sytuacyjny omawianej problematyki dosyć wyraźnie wskazuje na szereg trudności, z którymi musi zmierzyć się nie tylko każdy uczeń, ale także każdy nauczyciel języka ${ }^{20}$. Z jednej strony uczeń musi zrozumieć, iż relacje pomiędzy każdymi dwoma (lub więcej) językami układać się będą zawsze na warunkach ekwiwalencji, z drugiej zaś strony każdy nauczyciel języka musi być w stanie uczniowi sytuację taką uzmysłowić. Oznacza to m.in. zastosowanie całej serii działań wskazujących zależność kontekstową każdego z określeń tworzących system językowy opisujący (oznaczający) wszelkie zjawiska kulturowe z punktu widzenia rodzimych użytkowników danej kultury, podczas którego uczeń byłby w stanie dostrzec (i kognitywnie utrwalić) istnienie takiej odrębności kulturowoopisowej. Oznacza to także świadome zaprojektowanie serii postępowań glottodydaktycznych pozwalających uczniowi na internalizację wszelkich istotnych dla danego systemu językowo-kulturowego (a także dla jakości komunikowania się w konkretnym systemie) pojawiających się różnic strukturalno-semantycznych pomiędzy oboma językami.

Tu właśnie istotną funkcję odgrywać będzie, posiadana przez nauczyciela, eksplicytna wiedza glottodydaktyczna. Wiedza ta dotyczyć będzie nie tylko kwestii związanych z odpowiedzią na pytanie: „jak uczyć?”, lecz również na niezwykle istotne pytanie: „czego uczyć?”. Z jednej strony jest tu więc mowa o dydaktycznych zasadach merytorycznych, z drugiej zaś - o wielu zagadnieniach dotyczących indywidualnych projekcji językowych każdego z nauczycieli języka (zob. badania Robinsona i Longa na ten temat) ${ }^{21}$. Bez wątpienia, najważniejszą z nich (aczkolwiek nie jedyną) jest kwestia świadomości języka nauczyciela języka obcego, czyli zjawisko, które zostało w bardzo wyraźny sposób odróżnione od zagadnień ogólnej świadomości języka ${ }^{22}$. Ogólna świadomość języka, to według Bachmana ${ }^{23}$, kompetencja językowa, a według Bakera ${ }^{24}$ kompetencja komunikacyjna. Świado-

19 C. Kramsch, op. cit., s. 13-14.

20 Zob. E. Rostańska, Wymiana znaczeń między nauczycielem a uczniem w komunikacji werbalnej, [w:] Problemy edukacji lingwistycznej, M.T. Michalewska (red.), Katowice 1999, s. 109-113.

21 S. Andrews, op. cit., s. 32-33.

22 Ibidem, s. 56 i nast.

23 L. Bachman, Fundamental consideration in language testing, Oxford 1990, s. 88.

24 C. Baker, Foundations of bilingual education and bilingualism, Philadelphia 1997, s. 33. 
mość języka nauczyciela, z kolei, to sposób wykorzystywania swojego implicytnego poziomu znajomości nauczanego języka podczas kontaktów nauczyciela z obiektem nauczania czyli uczniem. Oba terminy oznaczają jednak ten rodzaj kompetencji, który pozwala użytkownikowi danego języka na - poziomowo uwarunkowany - przekaz informacyjny podczas wykorzystywania zasobów leksykonu mentalnego języka obiektywnie słabszego.

Bez wątpienia, musi pojawić się w tym kontekście pytanie dotyczące wpływu jednostkowej mocy języka ( $\mathrm{tj}$. indywidualnego potencjału kompetencyjno-lingwalnego) charakteryzującej nauczyciela na szybkość oraz efektywność budowy odpowiedniego poziomu kompetencji komunikacyjnej uczniów. Biorąc pod uwagę, iż poziom kompetencji komunikacyjnej ucznia zależny jest zarówno od szeregu czynników zewnętrznych (takich, jak - przykładowo - ustalony poziom ekspozycji ucznia na język), jak i wewnętrznych (np. sposób projekcji lekcji językowej w klasie), pojawia się pytanie dotyczące rankingowej istotności wspomnianych (oraz szeregu innych) czynników glottodydaktycznych na ucznia podczas jego pracy nad językiem. Zakładając, że np. ekspozycja ucznia na język może być regulowana nie tylko przy pomocy form/reguł administracyjnych, lecz także metaadministracyjnych, zależnych zarówno od ucznia, jak i nauczyciela, okazuje się, że ogólnie prezentowany przez ucznia poziom kompetencji komunikacyjnej zależy w dosyć istotnym stopniu od projekcji lekcji językowej, której podlega uczeń podczas lekcji języka. Z jednej strony, poziom taki zależny będzie od samego „pomysłu na nauczanie”, którego autorem jest nauczyciel, z drugiej zaś - od poziomu jednostkowej świadomości językowej wspomnianego nauczyciela. Prezentowana przez nauczyciela wiedza eksplicytna, będąca w dużym stopniu wynikiem wcześniejszej, lecz dosyć konsekwentnie realizowanej osobistej ekspozycji nauczyciela na język, oznacza pojawienie się (bądź też nie) podczas zajęć lekcyjnych szeregu działań glottoedukacyjnych, będących wyraźną promocją nie tylko sposobów i technik uczenia się danego języka, ale także (a może przede wszystkim) jego komunikacyjnego używania. Takie funkcjonowanie nauczyciela w klasie sprzyjać także będzie konsekwentnemu budowaniu leksykonu mentalnego uczniów, którzy w ten sposób poszerzać będą nie tylko zasób informacji związanych z wiedzą deklaratywną (opisującą, przy pomocy języka, kulturowo osadzone zjawiska i doświadczenia), lecz także z wiedzą proceduralną, dotyczącą zastosowania dla opisu ogólnie odbieranej rzeczywistości pojawiających się w języku strategii i procedur. Ponieważ zaś nauczanie drugiego języka rozpoczyna się z reguły w momencie, gdy uczniowie opanowali już zasady opisu rzeczywistości przy pomocy języka rodzimego, to właśnie poziom świadomości nauczanego języka u nauczyciela będzie (powinien być) tym orężem, który uchronić ma ucznia przed popełnieniem różnego rodzaju błędów językowych związanych chociażby ze zjawiskiem interferencji, często skutecznie uniemożliwiającym 
uczniowi uzyskanie względnie wysokiego poziomu kompetencji komunikacyjnej. Wtedy właśnie nauczyciel powinien wiedzieć, w jaki sposób posiadana przez ucznia wiedza implicytna dotycząca poznawanego języka (a także pojawiających się różnic i podobieństw pomiędzy L1 i L2) może zostać przez niego wykorzystana do skutecznej budowy coraz bardziej pełnych sposobów komunikacji, kiedy zaś zasób wspomnianej wiedzy okazać się może niewystarczający i/lub niepożądany. Teza, że świadomość języka nauczyciela stanowi istotną zmienną pomagającą lub też utrudniającą uczniowi jego pracę nad językiem stanowi istotny problem badawczy, którego rozsupłanie pomóc może uczniom w ich działaniach glottodydaktycznych o różnym stopniu natężenia.

\section{4. Świadomość językowa nauczyciela jako jednostka glottodydak- tyczna}

Definicje świadomości językowej nauczyciela spotkać można w wielu publikacjach naukowych ${ }^{25}$, najpełniej jednak wydaje się opisywać ją Andrews (2007). Zgodnie z zaproponowaną przez niego definicją, świadomość językowa nauczyciela nie odnosi się jedynie do kwestii formalnych (takich jak np. wyczucie języka), ale obejmuje o wiele szerszy zakres sięgając od kwestii kulturowych, poprzez zagadnienia pragmatyki języka, aż do zakresów informacyjnych związanych z przekazywaniem kontekstowych właściwości konkretnych określeń istniejących w tkance kulturowej języka. Andrews ${ }^{26}$ ustala nawet listę dwunastu wyszczególnionych zagadnień ilustrujących - zgodnie z jego koncepcją - stopień obeznania się nauczyciela z językiem. Zgodnie z przedstawioną listą, nauczyciel niewykazujący zbyt wysokiego stopnia świadomości językowej nie jest w stanie poprawnie funkcjonować w klasie językowej o dowolnym stanie poziomowym kompetencji komunikacyjnej uczniów. W tym względzie, zresztą, Andrews w zupełności zgadza się zarówno $z$ Leechem ${ }^{27}$, jak i Thornburym ${ }^{28}$, którzy szczegółowo wymieniają, czego nie będzie w stanie wykonać w klasie nauczyciel nieposiadający

25 Zob. np. B. van Lier, Introducing language awareness, London 1995, s. 232; B. van Leer, Interaction in the language curriculum: Awareness, autonomy and authenticity, London 1996, s. 126; R. Carter, How aware should language teachers and learners be?, Paper presented at the International Language in Education Conference, Hong-Kong, 14-16 December 1994; J.M. Sinclair, Language awareness in six easy lessons, [w:] Language awareness - NCLE Reports and Papers, G. Donmall (red.), London 1985, s. 33-37.

26 S. Andrews, op. cit., s. 35.

27 G. Leech, Students' grammar - teachers' grammar - learners' grammar, [w:] Grammar and the language teacher, M. Bygate, A. Tonkyn, E. Williams (red.), Hemel Hempstead 1994, s. 18.

28 S. Thornbury, About language, Cambridge 1997, s. xii. 
zbyt wysokiego stopnia świadomości języka. Bez względu na to, czy - idąc śladem wspomnianych wcześniej badań, których autorami są Long i Robinson ${ }^{29}$ - zwróci się uwagę na preferowany styl nauczania języka, czy też na końcowe (całościowe) efekty jego pracy (zgodnie z supozycją Larsen-Freeman ${ }^{30}$ ), w każdym wypadku zmienna określająca świadomość językową nauczyciela odgrywać będzie bardzo ważną rolę podczas konstrukcji (oraz, później, oceny) inputu, zarówno w sekwencji cząstkowej (input lekcyjny), jak i bardziej rozszerzonej (input rozdziału książki, serii lekcji, sylabusa itd.). W każdej z wymienionych sytuacji świadomość językowa nauczyciela odgrywać będzie rolę kwalifikującą, bezpośrednio wpływającą na styl pracy i postępy językowe uczniów.

Sporządzona przez Andrewsa lista faktów glottodydaktycznych, która może zostać uznana za miernik potencjału językowego języka nauczanego każdego z nauczycieli tego języka, wyraźnie wskazuje, że każda z umieszczonych tam kwestii musi zostać bezwzględnie wzięta pod uwagę, ponieważ posiada bezpośrednie „przełożenie” na jakość produkcji języka u uczniów. Tak więc, przykładowo, nauczyciel mylący się w rozróżnianiu odcieni semantycznych określeń biorących udział w jednostkowym procesie komunikacyjnym nie będzie w stanie przekazać tych różnic swoim uczniom, co z kolei doprowadzi do sytuacji, iż oni sami, tak jak będą w stanie to zrobić, będą zmuszeni do ich poszukania. W efekcie pojawić się musi wiele z cech lingua franca (np. maniera używania hiperonimów, bądź też cecha hasłowego opisu rzeczywistości). Działalność taka doprowadzi do pojawienia się w działalności komunikacyjnej uczniów pewnych form hybrydowych bądź nawet elementów fosylizacyjnych, co w skrajnych wypadkach doprowadzi do większych lub mniejszych trudności uczniów w ich usiłowaniach porozumiewania się z innymi użytkownikami języka.

Podobne wnioski wysnuć można podczas analizy każdego $\mathrm{z}$ wyszczególnionych przez Andrewsa punktów, ilustrujących formy pomiaru potencjału glottodydaktycznego nauczycieli języka obcego. Jeśli weźmie się pod uwagę fakt, iż właściwymi gospodarzami lekcji językowej (podobnie jak każdej innej lekcji) są uczniowie, nauczyciel zaś w wielu wypadkach pełni tam rolę nadzorującego ich pracę mentora, okaże się, że świadomość języka nauczyciela, która - jak powiedziano - nie może ograniczać się jedynie do kwestii wrażliwości na język sensu stricto, lecz która rozciąga się także na sferę umiejętnego przekazu tychże informacji uczniom, odgrywać będzie istotną rolę w każdym momencie zajęć językowych i nawet nauczyciel o wysokim stopniu wrażliwości na język, niepotrafiący

29 M. Long, P. Robinson, Focus on form: Theory, research and practice, [w:] Focus on form in classroom second language education, C. Doughty, J. Williams (red.), Cambridge 1998, s. 15-41.

30 D. Larsen-Freeman, The grammar of choice, [w:] New perspectives on grammar teaching in second language classrooms, E. Hinkel, S. Fotos (red.), Mahwah NJ 2002, s. 104. 
jednak w wystarczającym stopniu podążyć tropem myślenia swoich uczniów, może mieć problemy z przekazem treści językowych oraz internalizacją tychże przez uczniów.

Istotną rolę podczas analizy sporządzonej przez Andrewsa listy odgrywa - jak się wydaje - kolejność umieszczonych tam zdarzeń glottodydaktycznych. Ponieważ lista ta jest wynikiem badań ankietowych jej autora (Andrews zapytał o te kwestie osoby przygotowujące rodzimych użytkowników języka angielskiego do pracy $\mathrm{w}$ charakterze nauczyciela angielskiego jako języka obcego), wszelkie z istniejących na niej informacji odgrywają istotną - jak należy sądzić - rolę podczas ustalania sylwetki językowej (oraz glottodydaktycznej) nauczyciela języka angielskiego jako obcego. Zrozumiałą jest rzeczą, że ustalenie potencjału języka nauczanego w odniesieniu do nauczycieli nienatywnych powinno wziąć pod uwagę przede wszystkim kwestie ich nienatywności (co oznacza nieco mniejszą możliwość semantycznego poziomowania określeń oraz nieplanowany wzrost akceptacji dla używania w procesach komunikacyjnych, powodujących pojawianie się hasłowości, hiperonimów), należy jednak w miarę wyraźnie określić granice ogólnej akceptacji wspomnianego potencjału języka absolutnie niezbędnego do pracy $\mathrm{z}$ daną grupą poziomową (przykładowo, należy ustalić bezwzględnie konieczny poziom potencjału językowego, w tym stopnia 'wrażliwości' nauczyciela na język, dla nauczycieli pracujących z grupami początkującymi, jak również w odniesieniu do grup o wyższym stopniu kompetencji komunikacyjnej, aby w każdym wypadku kurs został przez jego uczestników określony pozytywnie). Andrews dosyć wyraźnie wskazuje, dzięki hierarchicznemu ustawieniu zdarzeń glottodydaktycznych mających wpływ na ustalenie potencjału poziomu świadomości językowej danego nauczyciela języka obcego, jakie elementy endolingwalne i endodydaktyczne odgrywać będą istotną rolę podczas profesjonalnego traktowania przez nauczyciela języka swoich obowiązków zawodowych. Umieszczając, przykładowo, na drugim (wysokim) miejscu kwestie związane z rozumieniem pojęć dotyczących konkretnych określeń lingwalno-strukturalnych, wskazuje Andrews na istotność wzięcia pod uwagę możliwości kognitywnych nauczyciela języka, który powinien wiedzieć (oraz objaśnić zainteresowanym uczniom) dlaczego użycie danego określenia jest semantycznie w danej sytuacji najbardziej właściwe oraz jak zmieni się sens logiczno-semantyczny danego opisu sytuacyjnego, jeśli zostanie wykorzystane inne (semantycznie bliskoznaczne) określenie.

Wspomniana sytuacja oznacza, iż Andrews - świadomy odpowiedzialności, jaką ponosi nauczyciel języka za efekty swojego działania pedagogicznego - dosyć wyraźnie podkreśla pojawiającą się spójność logiczną pomiędzy jednostkowym poziomem świadomości języka danego nauczyciela oraz poziomem kompetencji komunikacyjnej jego uczniów. Podkreślenie to zresztą dosyć jasno łączone jest ze 
wspomnianą opinią Thornbury’ego ${ }^{31}$, gdy wyszczególniony zostaje pogląd wspomnianego badacza, czego nie będzie umiał zrobić nauczyciel języka, gdy poziom świadomości jego języka nie jest zbyt wysoki (np. pojawi się brak możliwości dobrego i akuratnego projektowania zajęć lekcyjnych, niezbyt duże możliwości interpretacyjne tych części sylabusów, na których oparte są działania glottodydaktyczne z wykorzystaniem podręczników, brak zdolności perswazyjno-motywujących wyjaśniających uczniom istotę poznania i opanowania konkretnych wzorców leksykalno-strukturalnych, słabe perspektywy przekonania uczniów do ogólnych celów nauki języka jako nauki przez całe życie). W ten sposób, jak wynika $\mathrm{z}$ przedstawionej przez Andrewsa listy ${ }^{32}$, poziom potencjału świadomości języka u każdego z nauczycieli staje się zmienną ilustrującą całą operacjonalną działalność zawodową nauczyciela języka. Im wyższy poziom znajomości języka docelowego u nauczyciela, tym lepsza jakość nauczania tego języka; im pełniejsze możliwości rozumienia pozycji ucznia podczas lekcji językowej, tym bardziej trafne sposoby działań glottodydaktycznych wykorzystywane przez nauczyciela podczas lekcji języka. Nauczyciel języka powinien nie tylko wiedzieć, dlaczego konkretne rozwiązanie leksykalno-strukturalne będzie tym kontekstowo najpełniej wpisującym się $\mathrm{w}$ proces przekazu informacyjnego, lecz także, jakie techniki glottodydaktyczne należy wdrożyć, aby skutecznie umożliwić swoim uczniom opanowanie przedstawianych im rozwiązań leksykalno-syntaktycznych. W tym sensie, rodzaj oraz intensywność inputu wprowadzonego przez nauczyciela podczas konkretnej jednostki lekcyjnej, jak i podczas dłuższego okresu działań glottodydaktycznych w dużej mierze opiera się - oprócz innych istotnych elementów - na jakości języka posiadanego przez nauczyciela, czyli na konkretnym jednostkowym poziomie jego bilingwizmu ${ }^{33}$.

\section{Podsumowanie}

Przedstawione powyżej zagadnienia stanowią jedynie cząstkę szeregu problemów i uwag. Pojawia się jednak zawsze nadzieja, że być może niektórym z nich dane będzie, aby porozmawiać o nich nieco dłużej. Pytanie, jak praktycznie pogodzić wspomnianą przez de Saussure’a opozycję langue - parole w sytuacji, gdy prymarne nastawienie całego szeregu uczniów pragnących nauczyć się języka oznacza wykazanie zapotrzebowania na parole, podczas

31 Ibidem, s. xii.

32 Ibidem, s. 35-36.

33 Na ten temat więcej w mojej książce: Nauczyciel bilingwalny. Sylwetka językowa nauczyciela języka angielskiego jako obcego, Łask 2010. 
gdy w wielu wypadkach istniejące curricula i/lub podstawy programowe kładą wyraźny nacisk na langue, w dalszym ciągu pozostaje bez odpowiedzi. I tylko nauczyciel - ten dyrygent orkiestry zwanej glottodydaktyką - jest w stanie udzielić jej przynajmniej częściowo.

\section{Bibliografia}

Andrews S., Teacher language awareness, Cambridge 2007.

Bachman L., Fundamental consideration in language testing, Oxford 1990.

Baker C., Foundations of bilingual education and bilingualism, Philadelphia 1997.

Bereźnicki F., Podstawy dydaktyki, Kraków 2011.

Carter R., How aware should language teachers and learners be? Paper presented at the International Language in Education Conference, Hong-Kong, 14-16 December 1994.

Dobek-Ostrowska B., Podstawy komunikowania społecznego, Wrocław 1999.

Goffmann E., Człowiek w teatrze życia codziennego, Warszawa 1981.

Kramsch C., Language and Culture, Oxford 1998.

Larsen-Freeman D., The grammar of choice, [w:] New perspectives on grammar teaching in second language classrooms, E. Hinkel, S. Fotos (red.), Mahwah 2002, s. 103-118.

Leech G., Students' grammar - teachers' grammar - learners' grammar, [w:] Grammar and the language teacher, M. Bygate, A. Tonkyn, E. Williams (red.), Hemel Hempstead 1994, s. 17-30.

van Leer B., Introducing language awareness, London 1995.

van Leer B., Interaction in the language curriculum: Awareness, autonomy and authenticity, London 1996.

Long M., Robinson P., Focus on form: Theory, research and practice, [w:] Focus on form in classroom second language education, C. Doughty, J. Williams (red.), Cambridge 1998, s. 15-41.

Philips D.H., Soltis J.F., Perspectives on learning, London 2004.

Ratner N., Gleason J., Psycholinguistics, Harcourt 2005.

Richards J.C., Rogers T.S., Approaches and methods in language teaching, Cambridge 2001.

de Saussure F., Écrits de linguistique générale, Paris 2002.

Sinclair J.M., Language awareness in six easy lessons, [w:] Language awareness NCLE Reports and Papers 6, G. Donmall (red.), London 1985, s. 33-37.

Skinner B.F., The science of teaching and the art of learning, „Harvard Educational Review” 1954, 24, s. 86-97.

Thornbury S., About language, Cambridge 1997.

Wichura H., Metody kształcenia poczatkowego, [w:] Praca nauczyciela $i$ ucznia w klasach 1-3, Warszawa 1990, [online], http://www.edukator.org.pl/2005a/wspieranie/wspieranie. html, [dostęp: 20.01.2016].

Yule G., The Study of Language, Cambridge 1998. 